\title{
Primary hyperparathyroidism in prostate cancer: guilty or not guilty?
}

\author{
G. Mazziotti ${ }^{1}$ S. Frara ${ }^{2} \cdot$ A. Mosca ${ }^{3}$
}

Received: 9 March 2018 / Accepted: 9 May 2018 / Published online: 30 May 2018

(c) Springer Science+Business Media, LLC, part of Springer Nature 2018

Skeletal health is a clinically relevant issue in patients with prostate cancer (PC) [1-3]. Bone is the most common site of PC cell migration with up to $90 \%$ of patients with advanced disease having bone metastases [4] with potential negative impact on quality of life and survival [5]. Since the first description of the "seed and soil" hypothesis by Stephan Paget in 1889 [6], several cellular signaling pathways, cytokines, chemokines, and adhesion molecules have been identified as players of cross-talking between PC cells and bone [7] attempting to relate them either to metastases diagnosis or to patients' prognosis (as prognostic factors) or to response to therapy (as predictive factors) [8].

Minisola et al. [9] recently performed a systematic assessment of mineral metabolism in 69 males with PC at different stages of disease as compared to 53 patients with non-prostate tumors of various origin. The most impressive result was the occurrence of primary hyperparathyroidism (PHPT) in $13 \%$ of patients with PC, a prevalence which was much higher than that expected in the general population [10]. Interestingly, two relevant considerations emerge from the Minisola et al. [9] retrospective data. First, in PC patients, PHPT was associated with higher Gleason score (GS), which is one of the best known prognostic factors [11]. As a consequence, it could be hypothesized that, if higher GS correlates with worse PC prognosis, and PHPT is associated with higher GS, PHPT could be related to a worse PC prognosis. Second, in the paper by Minisola et al. [9], PC patients with lower GS $(<7)$ and not submitted to androgen deprivation therapy (ADT) had a very low

G. Mazziotti

gherardo.mazziotti@asst-mantova.it

Endocrinology Unit, ASST Carlo Poma, Mantua, Italy

2 Chair of Endocrinology, Università Vita-Salute San Raffaele, Milan, Italy

3 Medical Oncology, 'Maggiore della Carità' University Hospital, Novara, Italy probability to express PHPT. Notably, PC with the best prognostic characteristics was considered "protective for PHPT" by Minisola et al. [9].

The pathophysiological determinants of these associations were not clarified in this study, but the authors hypothesized that in patients with higher PC activity/biological aggressiveness, as assessed by high GS, osteoblastic bone metastases may favor the development of PHPT by decreasing serum calcium values [9]. This editorial aimed at providing a different perspective of the aforementioned results, arguing that PHPT may be per se a risk factor for cancer development and/or progression [12]. In fact, Minisola et al. [9] reported relatively high prevalence of PHPT even in patients with non-prostate tumors of various origin. Previous studies reported an association between chronic parathyroid hormone (PTH) excess and breast, gastrointestinal, kidney, and thyroid cancers [1316] and PTH in excess was shown to favor tumor invasiveness with increase in bone metastatic burden [17]. PTH increases the availability of cytokines, such as interleukin6 , tumor necrosis factor- $\alpha$, and growth factors (transforming growth factor- $\beta$ ) in the bone microenvironment [18], possibly influencing the growth and survival of disseminated cells from tumors (e.g., breast cancer and PC) frequently homing the bone marrow [19] and even potentially favoring the resistance to chemotherapy and hormone deprivation therapies $[20,21]$. Moreover, experimental studies reported an up-regulation by PTH of matrix metalloproteinase-13 (also known as collagenase-3), an enzyme intimately associated with invasiveness of various cancers including PC and breast cancer [22]. Noteworthy, PTH has an amino-terminal sequence homology with PTHrelated protein [23], a hormone that stimulates cell growth and inhibits apoptosis in different cell types [24]. The cancer progression may be also favored by fibroblast growth factor-23 (FGF-23), which secretion is stimulated by PTH in excess [25]. Interestingly, in the study of Minisola et al. [9] serum FGF-23 values were associated with PHPT. 
Which is the clinical relevance of these results? First, the high prevalence of PHPT reported by Minisola et al. [9] may be a rationale for undertaking a pro-active screening of PHPT in patients with PC. Although hyperfunctioning parathyroid glands may be incidentally discovered by (11)Ccholine or (18)F-fluorocholine positron emission tomography performed for staging of PC [26], the biochemical diagnosis of PHPT in this clinical setting may be sometimes a clinical challenge. In fact, when osteoblastic bone metastases are present, calcium is entrapped in the bone and serum calcium values may not be so high as expected by the degree of PTH excess. On the other hand, PTH values may be high even in the absence of PHPT, in response to enhanced calcium demand and vitamin D deficiency, this latter condition being frequent in elderly males $[27,28]$. Besides the diagnostic aspects, high prevalence of PHPT in PC patients may be clinically relevant for both endocrinologist and oncologist. As in other similar clinical contexts [29-31], the pathogenesis of skeletal fragility in PC is multifactorial depending on tumor itself as well as on anti-neoplastic therapies [32]. As a matter of fact, vertebral and nonvertebral fragility fractures are frequent complications of ADT $[2,33]$ and skeletal-related events are also common in PC with bony metastasis, with consequent worsened quality of life and survival [5]. Although this issue was not specifically addressed by the study of Minisola et al. [9], it is expected that PHPT may correlate with increase in risk of fractures in patients exposed to ADT and in those with bone metastases. From an oncological point of view, measurement of PTH and diagnosis of PHPT may be important in clinical practice either for diagnosing biologically more aggressive PCs or for better defining PC patients prognosis, consistently with previous observations reporting an association between secondary PTH excess and PC progression [34, 35].

The study by Minisola et al. [9] may have also therapeutic implications. According to the current guidelines [36], rapid resolution of PHPT by a surgical approach is indicated when the disease is symptomatic (i.e., associated with renal insufficiency or with skeletal fragility) or when the patients are younger than 50 years or with serum calcium values $1 \mathrm{mg} / \mathrm{dl}$ above the upper of the reference laboratory range. For the other patients with PHPT, a clinical and biochemical surveillance is suggested [36]. Although prospective studies have not been so far published on this topic, the results of Minisola study [9] provide a preliminary rationale for choosing, whenever it is possible, the surgical correction of PTH excess due to hyperproduction by parathyroid glands in patients with PHPT and coexistent PC, regardless of serum calcium levels, renal function, and bone status.

In conclusion, the retrospective study by Minisola et al. [9] provides an intriguing evidence that PHPT may influence the outcome of PC. Future prospective trials with larger sample size are needed to clarify whether the measurement of PTH levels and the correction of PTH excess may change the prognosis of patients with PC.

\section{Compliance with ethical standards}

Conflict of interest G.M. received consultant fees from Ipsen and Novartis. S.F. and A.M. have no conflict of interest.

Research involving human participants and/or animals This article does not contain any studies with human participants or animals performed by any of the authors.

\section{References}

1. R.A. Adler, Prostate cancer treated with androgen deprivation therapy has consequences for bone. Endocrine 45(3), 339-340 (2014). https://doi.org/10.1007/s12020-013-0113-x

2. A.-C.M. Lassemillante, S.A.R. Doi, J.D. Hooper, J.B. Prins, O.R. L. Wright, Prevalence of osteoporosis in prostate cancer survivors: a meta-analysis. Endocrine 45(3), 370-381 (2014). https://doi.org/ 10.1007/s12020-013-0083-z

3. A.-C.M. Lassemillante, S.A.R. Doi, J.D. Hooper, J.B. Prins, O.R. L. Wright, Prevalence of osteoporosis in prostate cancer survivors II: a meta-analysis of men not on androgen deprivation therapy. Endocrine 50(2), 344-354 (2015). https://doi.org/10.1007/ s12020-015-0536-7

4. L. Bubendorf, A. Schopfer, U. Wagner, G. Sauter, H. Moch, N. Willi, T.C. Gasser, M.J. Mihatsch, Metastatic patterns of prostate cancer: an autopsy study of 1,589 patients. Hum. Pathol. 31(5), 578-583 (2000)

5. B.A. Gartrell, F. Saad, Managing bone metastases and reducing skeletal related events in prostate cancer. Nat. Rev. Clin. Oncol. 11(6), 335-345 (2014). https://doi.org/10.1038/nrclinonc.2014.70

6. D. Ribatti, G. Mangialardi, A. Vacca, Stephen Paget and the "seed and soil" theory of metastatic dissemination. Clin. Exp. Med. 6(4), 145-149 (2006). https://doi.org/10.1007/s10238-006-0117-4

7. F. Rahim, S. Hajizamani, E. Mortaz, A. Ahmadzadeh, M. Shahjahani, S. Shahrabi, N. Saki, Molecular regulation of bone marrow metastasis in prostate and breast cancer. Bone Marrow Res. 2014, 405920 (2014). https://doi.org/10.1155/2014/405920

8. S. D'Oronzo, J. Brown, R. Coleman, The role of biomarkers in the management of bone-homing malignancies. J. Bone Oncol. 9, 1-9 (2017). https://doi.org/10.1016/j.jbo.2017.09.001

9. F. Minisola, C. Cipriani, L. Colangelo, M. Cilli, A. Sciarra, M. Von Heland, L. Nieddu, E. Anastasi, R. Pascone, V. Fassino, D. Diacinti, F. Longo, S. Minisola, J. Pepe, Mineral metabolism abnormalities in patients with prostate cancer: a systematic case controlled study. Endocrine 59(2), 338-343 (2018). https://doi. org/10.1007/s12020-017-1351-0

10. M.W. Yeh, P.H. Ituarte, H.C. Zhou, S. Nishimoto, I.L. Liu, A. Harari, P.I. Haigh, A.L. Adams, Incidence and prevalence of primary hyperparathyroidism in a racially mixed population. J. Clin. Endocrinol. Metab. 98(3), 1122-1129 (2013). https://doi. org/10.1210/jc.2012-4022

11. N. Mottet, J. Bellmunt, M. Bolla, E. Briers, M.G. Cumberbatch, M. De Santis, N. Fossati, T. Gross, A.M. Henry, S. Joniau, T.B. Lam, M.D. Mason, V.B. Matveev, P.C. Moldovan, R.C.N. van den Bergh, T. Van den Broeck, H.G. van der Poel, T.H. van der Kwast, O. Rouviere, I.G. Schoots, T. Wiegel, P. Cornford, EAUESTRO-SIOG Guidelines on Prostate Cancer. Part 1: screening, diagnosis, and local treatment with curative intent. Eur. Urol. 71 (4), 618-629 (2017). https://doi.org/10.1016/j.eururo.2016.08.003 
12. U. Cinamon, R.E. Turcotte, Primary hyperparathyroidism and malignancy: "studies by nature". Bone 39(2), 420-423 (2006). https://doi.org/10.1016/j.bone.2006.01.146

13. M. Palmer, H.O. Adami, U.B. Krusemo, S. Ljunghall, Increased risk of malignant diseases after surgery for primary hyperparathyroidism. A nationwide cohort study. Am. J. Epidemiol. 127 (5), 1031-1040 (1988)

14. A.L. Pickard, G. Gridley, L. Mellemkjae, C. Johansen, A. KofoedEnevoldsen, K.P. Cantor, L.A. Brinton, Hyperparathyroidism and subsequent cancer risk in Denmark. Cancer 95(8), 1611-1617 (2002). https://doi.org/10.1002/cncr.10846

15. K.B. Michels, F. Xue, L. Brandt, A. Ekbom, Hyperparathyroidism and subsequent incidence of breast cancer. Int. J. Cancer 110(3), 449-451 (2004). https://doi.org/10.1002/ijc.20155

16. S. Palmieri, L. Roggero, E. Cairoli, V. Morelli, A. Scillitani, I. Chiodini, C. Eller-Vainicher, Occurrence of malignant neoplasia in patients with primary hyperparathyroidism. Eur. J. Intern. Med. 43, 77-82 (2017). https://doi.org/10.1016/j.ejim.2017.06.001

17. M.F. McCarty, Parathyroid hormone may be a cancer promoteran explanation for the decrease in cancer risk associated with ultraviolet light, calcium, and vitamin D. Med. Hypotheses 54(3), 475-482 (2000). https://doi.org/10.1054/mehy.1999.0880

18. S. Takahashi, M. Hakuta, K. Aiba, Y. Ito, N. Horikoshi, M. Miura, K. Hatake, E. Ogata, Elevation of circulating plasma cytokines in cancer patients with high plasma parathyroid hormone-related protein levels. Endocr. Relat. Cancer 10(3), 403-407 (2003)

19. F.C. Cackowski, R.S. Taichman, Parallels between hematopoietic stem cell and prostate cancer disseminated tumor cell regulation. Bone (2018). 10.1016/j.bone.2018.02.025

20. H. Huang, C. Wang, F. Liu, H.Z. Li, G. Peng, X. Gao, K.Q. Dong, H.R. Wang, D.P. Kong, M. Qu, L.H. Dai, K.J. Wang, Z. Zhou, J. Yang, Z.Y. Yang, Y.Q. Cheng, Q.Q. Tian, D. Liu, C.L. Xu, D.F. $\mathrm{Xu}$, X.G. Cui, Y.H. Sun, Reciprocal network between cancer stem-like cells and macrophages facilitates the progression and androgen deprivation therapy resistance of prostate cancer. Clin. Cancer Res. (2018). 10.1158/1078-0432.Ccr-18-0461

21. S.A. de Bessa Garcia, A.C. Pavanelli, E.M.N. Cruz, M.A. Nagai, Prostate apoptosis response 4 (PAR4) expression modulates WNT signaling pathways in MCF7 breast cancer cells: A possible mechanism underlying PAR4-mediated docetaxel chemosensitivity. Int. J. Mol. Med. 39(4), 809-818 (2017). https://doi.org/10. 3892/ijmm.2017.2900

22. M.F. Leeman, S. Curran, G.I. Murray, The structure, regulation, and function of human matrix metalloproteinase-13. Crit. Rev. Biochem. Mol. Biol. 37(3), 149-166 (2002). https://doi.org/10. 1080/10409230290771483

23. T.M. Murray, L.G. Rao, P. Divieti, F.R. Bringhurst, Parathyroid hormone secretion and action: evidence for discrete receptors for the carboxyl-terminal region and related biological actions of carboxyl- terminal ligands. Endocr. Rev. 26(1), 78-113 (2005). https://doi.org/10.1210/er.2003-0024

24. M. Iwamura, P.A. Abrahamsson, K.A. Foss, G. Wu, A.T. Cockett, L.J. Deftos, Parathyroid hormone-related protein: a potential autocrine growth regulator in human prostate cancer cell lines. Urology 43(5), 675-679 (1994)

25. S. Feng, J. Wang, Y. Zhang, C.J. Creighton, M. Ittmann, FGF23 promotes prostate cancer progression. Oncotarget 6(19), 17291-17301 (2015). https://doi.org/10.18632/oncotarget.4174

26. L. Michaud, A. Burgess, V. Huchet, M. Lefevre, M. Tassart, J. Ohnona, K. Kerrou, S. Balogova, J.N. Talbot, S. Perie, Is ${ }^{18} \mathrm{~F}-$ fluorocholine-positron emission tomography/computerized tomography a new imaging tool for detecting hyperfunctioning parathyroid glands in primary or secondary hyperparathyroidism? J.
Clin. Endocrinol. Metab. 99(12), 4531-4536 (2014). https://doi. org/10.1210/jc.2014-2821

27. R. Scalco, M.O. Premaor, P.E. Fröehlich, T.W. Furlanetto, High prevalence of hypovitaminosis D and secondary hyperparathyroidism in elders living in nonprofit homes in South Brazil. Endocrine 33(1), 95-100 (2008). https://doi.org/10.1007/s12020008-9061-2

28. J.-C. Souberbielle, C. Massart, S. Brailly-Tabard, E. Cavalier, P. Chanson, Prevalence and determinants of vitamin D deficiency in healthy French adults: the VARIETE study. Endocrine 53(2), 543-550 (2016). https://doi.org/10.1007/s12020-016-0960-3

29. R. Pedersini, S. Monteverdi, G. Mazziotti, V. Amoroso, E. Roca, F. Maffezzoni, L. Vassalli, F. Rodella, A.M. Formenti, S. Frara, R. Maroldi, A. Berruti, E. Simoncini, A. Giustina, Morphometric vertebral fractures in breast cancer patients treated with adjuvant aromatase inhibitor therapy: a cross-sectional study. Bone 97, 147-152 (2017). https://doi.org/10.1016/j.bone.2017.01.013

30. G. Mazziotti, A.M. Formenti, S. Frara, R. Olivetti, G. Banfi, M. Memo, R. Maroldi, R. Giubbini, A. Giustina, High prevalence of radiological vertebral fractures in women on thyroid-stimulating hormone-suppressive therapy for thyroid carcinoma. J. Clin. Endocrinol. Metab. 103(3), 956-964 (2018). https://doi.org/10. 1210/jc.2017-01986

31. G. Mazziotti, A.M. Formenti, M.B. Panarotto, E. Arvat, A. Chiti, A. Cuocolo, M.E. Dottorini, C. Durante, L. Agate, S. Filetti, F. Felicetti, A. Filice, L. Pace, T. Pellegrino, M. Rodari, M. Salvatori, C. Tranfaglia, A. Versari, D. Viola, S. Frara, A. Berruti, A. Giustina, R. Giubbini, Real-life management and outcome of thyroid carcinoma-related bone metastases: results from a nationwide multicenter experience. Endocrine 59(1), 90-101 (2018). https://doi.org/10.1007/s12020-017-1455-6

32. R. Rizzoli, J.J. Body, M.L. Brandi, J. Cannata-Andia, D. Chappard, A. El Maghraoui, C.C. Gluer, D. Kendler, N. Napoli, A. Papaioannou, D.D. Pierroz, M. Rahme, C.H. Van Poznak, T.J. de Villiers, El Hajj Fuleihan, G.: Cancer-associated bone disease. Osteoporos. Int. 24(12), 2929-2953 (2013). https://doi.org/10. 1007/s00198-013-2530-3

33. G. Mazziotti, E. Canalis, A. Giustina, Drug-induced osteoporosis: mechanisms and clinical implications. Am. J. Med. 123(10), 877-884 (2010). https://doi.org/10.1016/j.amjmed.2010.02.028

34. G.G. Schwartz, Prostate cancer, serum parathyroid hormone, and the progression of skeletal metastases. Cancer epidemiology, biomarkers \& prevention: a publication of the American Association for Cancer Research, cosponsored by the American Society of Preventive. Oncology 17(3), 478-483 (2008). https:// doi.org/10.1158/1055-9965.Epi-07-2747

35. A. Berruti, R. Cook, F. Saad, C. Buttigliero, A. Lipton, M. Tampellini, K.A. Lee, R.E. Coleman, M.R. Smith, Prognostic role of serum parathyroid hormone levels in advanced prostate cancer patients undergoing zoledronic acid administration. Oncologist 17 (5), 645-652 (2012). https://doi.org/10.1634/theoncologist.20110448

36. A.A. Khan, D.A. Hanley, R. Rizzoli, J. Bollerslev, J.E. Young, L. Rejnmark, R. Thakker, P. D'Amour, T. Paul, S. Van Uum, M.Z. Shrayyef, D. Goltzman, S. Kaiser, N.E. Cusano, R. Bouillon, L. Mosekilde, A.W. Kung, S.D. Rao, S.K. Bhadada, B.L. Clarke, J. Liu, Q. Duh, E.M. Lewiecki, F. Bandeira, R. D'Amour, C. Marcocci, S.J. Silverberg, R. Udelsman, K.S. Davison, J.T. Potts Jr., M.L. Brandi, J.P. Bilezikian, Primary hyperparathyroidism: review and recommendations on evaluation, diagnosis, and management. A Canadian and international consensus. Osteoporos. Int. 28(1), 1-19 (2017). https://doi.org/10.1007/s00198-016-3716-2 